\title{
Consistent and High Rates of Gene Transfer Can Be Obtained Using Flow-Through Transduction over a Wide Range of Retroviral Titers
}

\author{
ALICE S. CHUCK ${ }^{1,2}$ and BERNHARD O. PALSSON ${ }^{1,3}$
}

\begin{abstract}
Flow-through transduction methods have been developed to overcome physical limitations imposed by Brownian motion on retroviral delivery. This method uses net fluid flow of retroviral supernatants through a porous membrane on which the target cells are placed. It is shown that in comparison to static transduction methods, flow-through transductions have the following advantages: (i) flow-through transductions lead to transduction rates that exceed those obtained by static transduction; (ii) flow-through transductions lead to high transduction rates even at low viral concentrations, eliminating many of the concerns associated with the production of high-titer virus supernatants; (iii) flow-through transductions are insensitive to viral titers, eliminating the need to produce consistently retroviral supernatants at given virus concentrations; (iv) flowthrough transductions can be carried out without the use of polycations, such as polybrene; and (v) the volume of viral supernatants needed for gene transfer can be sharply reduced. Taken together, these advantages of flow-through transductions are likely to lead to their widespread use for gene transfer work, both in research and clinical settings.
\end{abstract}

\section{OVERVIEW SUMMARY}

Flow-through transduction provides a means by which high rates of gene transfer can occur without using high titers of virus vector. Reproducibly high numbers of transduced cells can be obtained with a wide range of virus titers, thus relaxing the requirement of set (high) titers within a transduction protocol. Incorporating flow-through transductions within clinical applications of gene therapy may also obviate the need for large volumes of high-titer virus produced by vector producer cell line cultures.

\section{INTRODUCTION}

$\mathbf{R}$ ETROVIRUSES ARE THE CURRENT VEHICLE OF CHOICE for stable gene delivery and expression in target cells (Ausubel, 1993), especially for the purpose of gene therapy (Crystal, 1995; Hodgson, 1995; Miller, 1992a; Mulligan, 1993). Retrovirusmediated gene transfer is typically carried out using static trans- duction protocols, where a liquid layer containing the retrovirus is placed on top of a bed of target cells. The physics of this transduction system may be described by three processes occurring simultaneously (Fig. 1): (i) Brownian motion of the retrovirus, (ii) decay of the retrovirus, and (iii) adsorption, or capture, of the retrovirus by the target cell. A retrovirus is a colloidal particle with a density similar to that of tissue culture medium, 1.16-1.18 g/ml (Lowy, 1985). Its root mean square displacement $(l)$ by Brownian motion over time $(t)$ can be described by (Einstein, 1905):

$$
l=\sqrt{2 D t}
$$

where $D$ is the diffusion coefficient. The numerical value of the diffusion constant for a retrovirus can be estimated from the Stokes-Einstein equation (e.g., Cussler, 1984) to be approximately $6.5 \times 10^{-8} \mathrm{~cm}^{2} / \mathrm{sec}$ using a viral diameter of $100 \mathrm{~nm}$ (Dubois-Dalq et al., 1984).

Retroviral half-lives $\left(t_{0.5}\right)$ are generally short (Levin and

\footnotetext{
${ }^{1}$ Department of Chemical Engineering, University of Michigan, Ann Arbor, MI 48109.

2Present address: Amgen Inc., 1840 DeHavilland Drive, Thousand Oaks, CA 91320.

${ }^{3}$ Present address: Department of Bioengineering, University of California, San Diego, La Jolla, CA 92093-0412.
} 


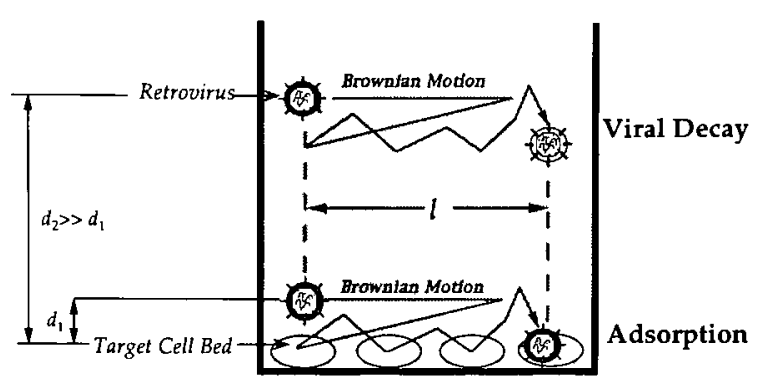

FIG. 1. Static transduction: Physical processes. This schematic shows how a retrovirus's distance from the target cell bed affects the probability of it being adsorbed. The virus close to the bed, at $d_{1}$, has a high probability of being adsorbed, while the virus further away, at $d_{2}$, decays over the same time period and thus cannot reach a target cell. Each retrovirus travels an average distance $l$ by Brownian motion over the time period of interest.

Rosenak, 1976; Sanes et al., 1986; Layne et al., 1989; Paul et al., 1993; Kotani et al., 1994). We have measured the half-life for a murine amphotropic retrovirus produced by the $\psi$ CRIP cell line (Danos and Mulligan, 1988) to be about 5-8 hr at $37^{\circ} \mathrm{C}$ (Chuck, 1995). Using the appropriate numerical values for the diffusion coefficient and half-life in equation (1), we estimate the distance that an average retroviral particle can travel within one half-life $\left(l_{0.5}\right)$ to be $480-610 \mu \mathrm{m}$. Because tissue culture procedures typically use liquid depths of $2-5 \mathrm{~mm}$, the majority of retroviruses in the transduction medium above a level of $480-610 \mu \mathrm{m}$ will not be able to reach the cell bed within one half-life. Only those particles closest to the target cells will be captured efficiently and within the time span of the retroviral half-life. We have shown that retroviruses within $500 \mu \mathrm{m}$ of the target cell bed were able to deliver the gene, whereas viruses further away did not contribute toward cell transduction (Chuck, 1995).

The importance of distance between the virus particle and target is depicted in Fig. 1, which shows a retrovirus particle's Brownian motion close to the target cell bed $\left(d_{1}\right)$ and far from the target cell bed $\left(d_{2}\right)$. The retroviruses close to the target bed are able to strike it many times, greatly increasing the chance of being captured by a target cell receptor. The retroviruses far away from the target may travel the same mean distance (l), but decay before being adsorbed by the target cells. Thus, by relying on Brownian motion to deliver the retrovirus to the target cells, as in static transductions, the rate of virus delivery is in large part determined by the proximity of the available viruses to the target cell, and the time in which the majority of viruses are still active (the half-life).

Under such physical limitations, the number of virions reaching the cell bed can be increased by increasing the retroviral titers. However, high retroviral titers have proven difficult to obtain from retroviral vector producer cell lines (Belmont et al., 1988; Bodine et al., 1990; Lynch and Miller, 1991; Crystal, 1995), and low retroviral titers are generally believed to be a major limitation of retrovirus-mediated gene transfer. Until recently, these low virus titers were limited by the concentration of virus that could be produced by retroviral vector producer cell lines. With the advent of new techniques for efficiently con- centrating a retrovirus solution (Paul et al., 1993; Kotani et al., 1994), the number of infectious retrovirus particles per unit volume of solution can be increased up to 10 - to 30 -fold. However, there remains the significant problem of variable viral titers produced by most producer cell lines (Miller, 1992b; Paul et al., 1993), making it difficult to reproduce yields from different preparations of virus solution. This variability may be addressed on a case-by-case basis using virus concentration methods, but combined with the large volumes of virus vector needed for clinical trials (Kotani et al., 1994), and the time consumed by adjusting the concentrations, the variability in virus yield makes the quality of virus solution very difficult to achieve from a virus production standpoint.

The limitations of Brownian motion can be overcome by directing the motion of the virus toward the target cells. Such a directed motion can be achieved by fluid flow, where retrovirus solution is passed through a porous membrane that supports the target cells, leading to significant increases in the number of successful gene transfer events. This procedure is termed "flowthrough transduction." Using this mode of transduction, the success of retroviral delivery is no longer dependent on high viral titers, and thus will not necessarily be limited by low retroviral titers. In the present study, the two methods of virus exposure, static and flow-through (Fig. 2A,B), were compared in their ability to deliver the virus to the target cells such that successful gene transfer occurred. Using static transduction methods, the number of successfully transduced cells is expected to depend on the virus concentration (Belmont et al., 1988; Lynch and Miller, 1991; Hughes et al., 1992; Buchschacher, 1993; Kotani et al., 1994), the number of available target cells (Lynch

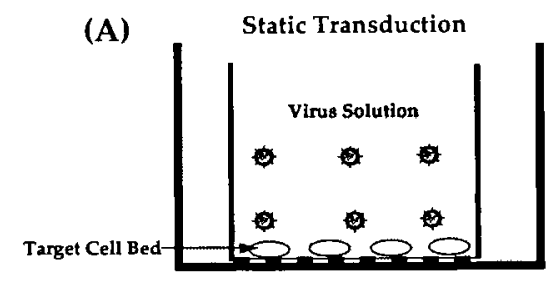

(B)

Flow-Through Transduction

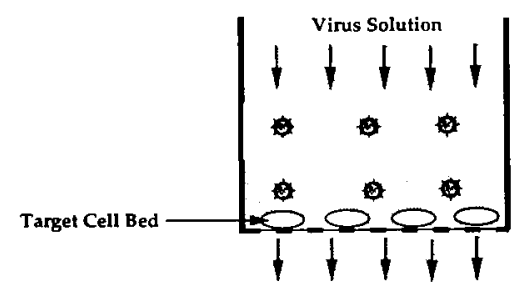

FIG. 2. Static transduction versus flow-through transduction. In static transduction (A), virus solution overlays a bed of target cells for the transduction period. In flow-through transduction (B), virus solution flows through the target cell bed for the duration of the transduction period. Flow-through transductions were always carried out in parallel with static transductions, using the same preparation of virus solution and the same target cell density. 
and Miller, 1991), and the polybrene level (Kaplan et al., 1967; Cornetta and Anderson, 1989). Polycations such as polybrene are found to be necessary for static retroviral transduction to take place. polybrene, especially at high levels, may be toxic to some target cells, and thus has not been approved for clinical use. Thus, it is desirable to reduce the dependence of retroviral-mediated gene transfer on polybrene. The effects of these factors on gene transfer rates in static and flow-through transduction protocols need to be studied and contrasted. We present such a study herein.

\section{MATERIALS AND METHODS}

\section{Cell culture}

The target cell line NIH-3T3 was seeded at 3,000 cells $/ \mathrm{cm}^{2}$ in either six-well plates (Costar, Cambridge, MA) or tissue culture membranes 1 day prior to transduction. Collagen-coated membranes (Transwell-COL ${ }^{\mathrm{TM}}$ cell culture inserts from Costar) were used. The Transwell-COL ${ }^{\mathrm{TM}}$ membranes are of the depth (filter) membrane type with a pore size rating of $0.4 \mu \mathrm{m}$, a diameter of $24.5 \mathrm{~mm}$, and a neutral charge. The estimated porosity of the Transwell-COL ${ }^{\mathrm{TM}}$ membrane is $\sim 50-60 \%$. The producer cell line used was kindly provided by Dr. James Wilson (construction of a similar vector is described in Wilson $e t$ al., 1988 ) and was produced by transfecting a pMFG vector containing a lacZ gene into $\psi$ CRIP (Danos and Mulligan, 1988). The retrovirus yielded from the producer cell line belonged to the murine leukemia virus (MuLV) family. All cell lines were grown with $10 \%$ calf serum supplement (GIBCO, Grand Island, $\mathrm{NY}$ ) in DMEM and were cultured at $37^{\circ} \mathrm{C}$ and $5 \% \mathrm{CO}_{2}$.

\section{Retrovirus supernatant}

Replication-defective retrovirus producer cells were thawed every 6 weeks, grown in 10-ml tissue culture dishes (Falcon, Becton Dickinson, Franklin Lakes, NJ), and cultured as described above. Medium that was conditioned for $24 \mathrm{hr}$ by a confluent monolayer of producer cells was filtered through $0.4-\mu \mathrm{m}$ pore-sized filters (low protein binding Sterile Acrodisc ${ }^{\mathrm{TM}}$, Gelman, Ann Arbor, MI). The retroviral vector used did not contain a secondary marker gene (such as one providing for neomycin resistance), and virus concentration was based on virus medium harvested from producer cells (grown as described above), which was given a unitless concentration value of 1.0. Variable retroviral concentrations were achieved by diluting this virus medium (relative retroviral concentration value $=1.0$ ) with growth medium. polybrene (Aldrich, Milwaukee, WI) was added to $4 \mu \mathrm{g} / \mathrm{ml}$ (unless otherwise stated). Negative controls (mock transductions) were prepared by adding polybrene (at the same levels as in the virus supernatant) to growth medium. These controls were carried out using both the static and flow-through transduction procedures.

\section{Retrovirus concentration}

Retrovirus supernatant (relative retroviral concentration = 1.0) was concentrated using the Pellicon Tangential Flow System (Millipore, Bedford, MA) equipped with an ultrafiltration membrane of $300-\mathrm{kD}$ molecular weight cutoff (Millipore
\# 300,000 NMWL PTMK000C5). Before each concentration, the ultrafiltration chamber was sterilized with 6 liters of 400 ppm sodium hypochlorite solution, flushed with 6 liters of regular tap water, and stored in $500 \mathrm{ml}$ of $1 \%$ formalin solution. On the day of concentration, the chamber was flushed with 2 liters of sterile PBS followed by 1 liter of DMEM. To prepare the virus concentrate, 1.5 liters of virus supernatant was harvested, then centrifuged in 50-ml aliquots in a Beckman table top centrifuge for $10 \mathrm{~min}$ at $1,500 \mathrm{rpm}(\sim 400 \times \mathrm{g})$. The virus solution was pumped (Millipore peristaltic pump, Model no. XX80-EL000) through the ultrafiltration unit at room temperature with an input gauge pressure of less than 5 psi. Filtered virus solution was washed with 2 liters of DMEM and recycled (concentrated) to a sterile 600-ml IV bag. The media that had passed through the membrane was collected and discarded. Virus concentration took place over a period of $1 \mathrm{hr}$, and serum was added to the final product at $10 \%$ to maintain the stability of the virus (measured to be $5-8 \mathrm{hrs}$ at $37^{\circ} \mathrm{C}$ in $10 \%$ serum) and to be consistent with the medium used for dilution. The degree of concentration was calculated from the virus medium volume reduction: e.g., 1.5 liters of virus medium concentrated to 0.105 liter gave a relative virus concentration of 14.3 . The concentrated retroviral supernatant was also filtered through $0.4-\mu \mathrm{m}$ pore-sized filters (Gelman, Ann Arbor, MI). Variable retroviral concentrations were achieved by diluting the concentrated virus supernatant (relative retroviral concentration $=$ 14.3) with growth medium ( $10 \%$ serum). Because some virus activity was lost upon concentration (i.e., recovery rates were usually less than $100 \%$ and typically $50 \%$ ), the viral activity of the solution diluted from a concentrated stock may not be the same as that from unconcentrated virus solution. For example, the activity of a solution diluted to relative retroviral concentration of 1.0 from 14.3 may not be the same as the original virus harvest (relative retroviral concentration designated as 1.0 ). Thus, the virus solutions used for each concentration value were derived from the same stock of solution (here, the relative retroviral concentration was 14.3). Polybrene (Aldrich) was added to the solutions at $4 \mu \mathrm{g} / \mathrm{ml}$.

\section{Static transductions}

Medium was removed from target cell cultures and replaced by $2 \mathrm{ml}$ of virus supernatant. (A schematic of the procedure shown in Fig. 2A.) The cultures were then incubated for the determined transduction time ( $8-9 \mathrm{hr}$, as specified in the legend), after which static transduction was stopped by removing retrovirus solution and adding fresh growth medium. Cultures were assayed for expression of transduced gene 3-4 days later. Because there was no significant difference between the growth of transduced cells and mock-transduced cells (Chuck, 1995), the transduction efficiencies were expected to remain the same throughout the period of culture.

\section{Flow-through transductions}

Virus medium flowed through the seeded Transwell-COL ${ }^{\mathrm{TM}}$ membranes at $\sim 1 \mathrm{ml} / \mathrm{hr}$ for up to $9 \mathrm{hr}$ at $37^{\circ} \mathrm{C}$. Gravity was used to induce the flow. (Schematic shown in Fig. 2B.) (Flow times are specified in legend). All transductions were done in parallel with static transductions. Flow-through transductions were stopped by removing retrovirus solution from the reser- 
voir above the target cell bed and adding fresh growth medium. Cultures were left to incubate (without media flow) for 3-4 days until the time of assay.

\section{Flow cytometry}

The product of the transduced gene, $\beta$-galactosidase ( $\beta$-Gal), reacts with fluorescein di- $\beta$-D-galactopyranoside (FDG) to form a product that is detectable using flow cytometry. To determine the percentage of cells infected, the cells were prepared in the following manner. Each cell culture insert was washed three times with $2 \mathrm{ml}$ of Hanks' balanced salt solution (HBSS) and the cells removed by $1 \mathrm{ml}$ of trypsin (GIBCO) exposure. Fresh growth medium was then used to resuspend and wash the cells. Reagents from the FluoReporter lac $Z$ gene detection kit from Molecular Probes (Eugene, OR) were used to prepare and stain the cells. The cells were incubated in a $37^{\circ} \mathrm{C}$ water bath for 5 min and then loaded with substrate by hypotonic shock as follows: $50 \mu \mathrm{l}$ of $2 \mathrm{mM}$ FDG was added to each tube at $37^{\circ} \mathrm{C}$ and left to incubate for $90 \mathrm{sec}$. The tubes were then immersed into ice, and $450 \mu \mathrm{l}$ of ice-cold phosphate-buffered saline (PBS) with human $\mathrm{IgG}$ (Sigma) and $1 \mathrm{mg} / \mathrm{ml}$ propidium iodide (PI) was added. Samples tubes were kept in ice until time of assay.

A Coulter EPICS flow cytometer was used to measure percentage of cells transduced. The following three selection criteria were used. First, single cells were selected from a 90LSFALS 2D dot plot and used to create a red (PI) fluorescence histogram. Second, this PI histogram was used to select live cells based on their low PI signal. Next, $\beta$-Gal expression from these live cells was indicated by amount of signal on a fluorescein fluorescence histogram (Fig. 3), where the fluorescence channel number indicates the degree of fluorescein fluorescence. In transduced cell populations, these fluorescein histograms usually consisted of two peaks: one representing cells positive for $\beta$-Gal expression, the other representing cells negative for $\beta$-Gal expression. The location of the lower fluorescence peak corresponded to the single peak observed with the autofluorescence (no FGD staining) and the mock transduction controls. The third and final selection was to measure percentage of cells in the positive peak (Fig. 3), calculated by dividing the area in the positive fluorescence (transduction) peak by the total histogram area. Transduction efficiency is denoted by percentage of cells transduced. All samples were assayed within $6 \mathrm{hr}$ after staining. Replicate samples were run in the latter half of this period, and early samples were rerun at the end. No differences in fluorescein signals were observed as a function of time of assay.

\section{RESULTS}

Important to retrovirus vector use, we show that increased virus concentration will not always lead to increased transduction rate. Rather, there is an optimal retroviral concentration for gene transfer, after which gains in transduction no longer occur with increased virus concentration. Second, we show the number of cells transduced depends on viral titers and polybrene levels. These dependencies are compared using the two methods of transduction, flow-through and static.
(A)

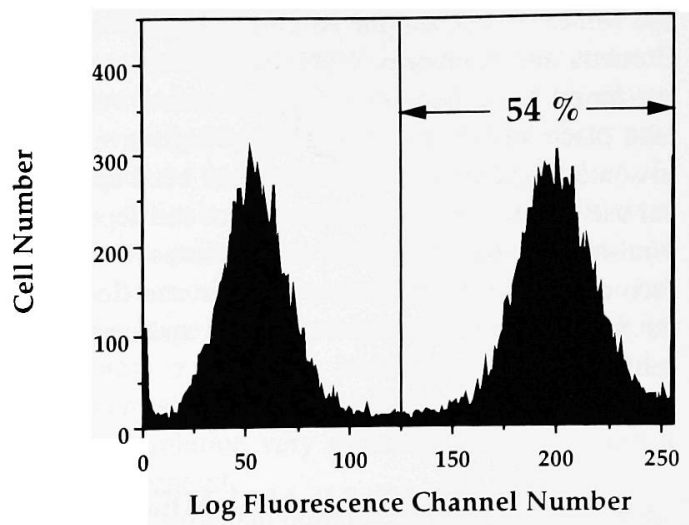

(B)

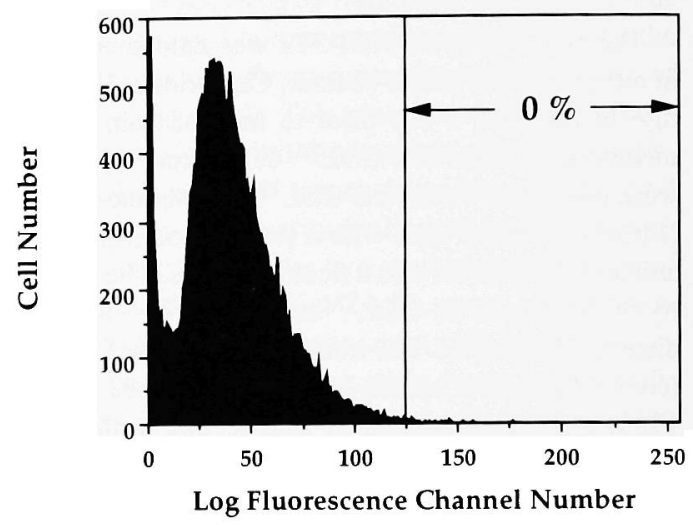

FIG. 3. Transduction efficiency as measured by flow cytometry. A. A representative histogram is shown depicting the bimodal peaks in fluorescein fluorescence (on a log channel number scale), representing $\beta$-Gal expression of a partially transduced population of cells. Here, $54 \%$ percent of the cell population expressed the transduced gene, as indicated by the percentage of live cells lying above log fluorescence channel number 125 . B. A histogram of a mock-transduced cell population shows $0 \%$ of the cells were transduced.

Using static transduction methods, the number of cells transduced was found to depend strongly on the virus concentration (Fig. 4). As expected, starting with low virus concentration, the number of transduced cells increased with increasing virus concentration. However, this increase did not continue as the virus concentration reached higher levels. Rather, the number of transduced cells reached a maximum and declined thereafter with increasing virus concentration. Thus, over the virus concentration range examined there was an "optimal" virus concentration that resulted in the maximal number of transduced cells.

Transduction efficiency as a function of virus concentration was also found to depend strongly on polybrene concentration (Fig. 4). The polybrene concentrations used ranged from 0 to $22 \mu \mathrm{g} / \mathrm{ml}$. Except in the absence of polybrene where no transduction occurred, the gene transfer rates showed the same dependence on viral concentration (as evidenced by the similar shaped profiles): An apparent peak in the number of successfully transduced cells occurred at 0.5 relative viral concentra- 


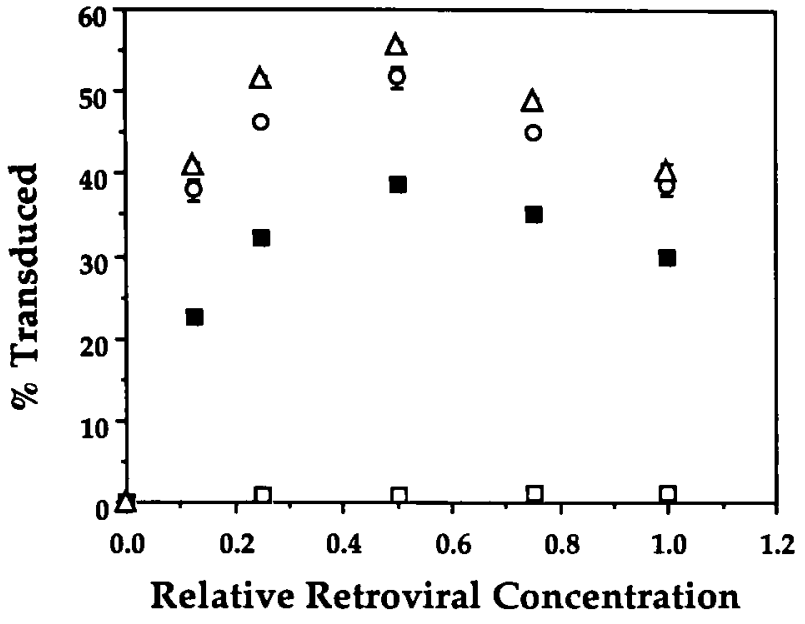

FIG. 4. Static transduction: Effect of virus and polybrene concentrations. Gene transfer as indicated by percentage of cells transduced (\% Transduced) was measured as a function of virus concentration and polybrene levels. Polybrene concentrations

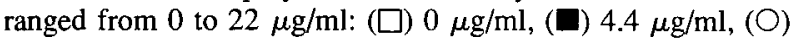
$13.2 \mu \mathrm{g} / \mathrm{ml},(\triangle) 22 \mu \mathrm{g} / \mathrm{ml}$. Only the static method of transduction was used here, and the transduction period was $8.5 \mathrm{hr}$. Each data point represents the average of two independent samples.

tion units. Maximal values ranged from $38 \%$ to $55 \%$ transduction with increased levels of polybrene. Further enhancements in gene transfer from increased concentrations of polybrene were no longer apparent after $13.2 \mu \mathrm{g} / \mathrm{ml}$. No evidence of cell toxicity was observed for polybrene levels of $13.2 \mu \mathrm{g} / \mathrm{ml}$ or less. Some cell toxicity (as detected by $\sim 20 \%$ fewer viable cells recovered at time of $\beta$-Gal assay) was observed when $22 \mu \mathrm{g} / \mathrm{ml}$ polybrene was used.

The percentage of cells transduced using both the flowthrough and static methods of transduction was measured as a function of virus concentration (Fig. 5A). The virus concentrations used spanned a thousand-fold range. Using either method, an apparent peak occurred in each of the profiles of number of transduced cells (Fig. 5A). These apparent peak points represent the maximum number of transduced cells achieved with each delivery method, and can each be associated with "optimal" virus concentrations. Unlike the results shown in Fig. 4, it is not clear whether these apparent peaks in Fig. 5 represent the beginnings of plateaus or true peaks.

There was a 10-fold difference between the optimal virus concentrations using the two different modes of transduction (Fig. 5): 0.6 relative concentration units for flow-through compared with 6 relative concentration units for the static transductions. There was also an approximately 1.5 -fold increase in the maximum number of transduced cells: $90 \%$ of the cells were transduced using flow-through and $58 \%$ for static. It should be noted that different batches of virus were used in the experiments described in Figs. 4 and 5. Although the virus solution for each experiment was prepared as described in Materials and Methods, the activity of each viral preparation can vary, and relative concentration values may not correspond in absolute activities between experiments. The greater than 10 -fold difference between static transduction peak locations in Fig. 4 and
Fig. 5 was attributed to variation in virus activity between the viral preparations used.

For a given virus concentration and target cell number, the number of cells transduced using the flow-through method was always higher than using the static method (Fig. 5). The enhancement in the number of transduced cells was greatest at the lowest virus concentrations used (Fig. 5B). Importantly, the flow-through method resulted in a consistently high rate of transduction over a wide range (more than two logs) of virus concentration. No differences in cell growth among the different virus concentration samples or between the methods of transduction were observed at time of assay ( $3-4$ days posttransduction).

Not only was the flow-through transduction method relatively insensitive to virus concentration, but unlike the static method, it did not require polybrene to obtain high rates of gene
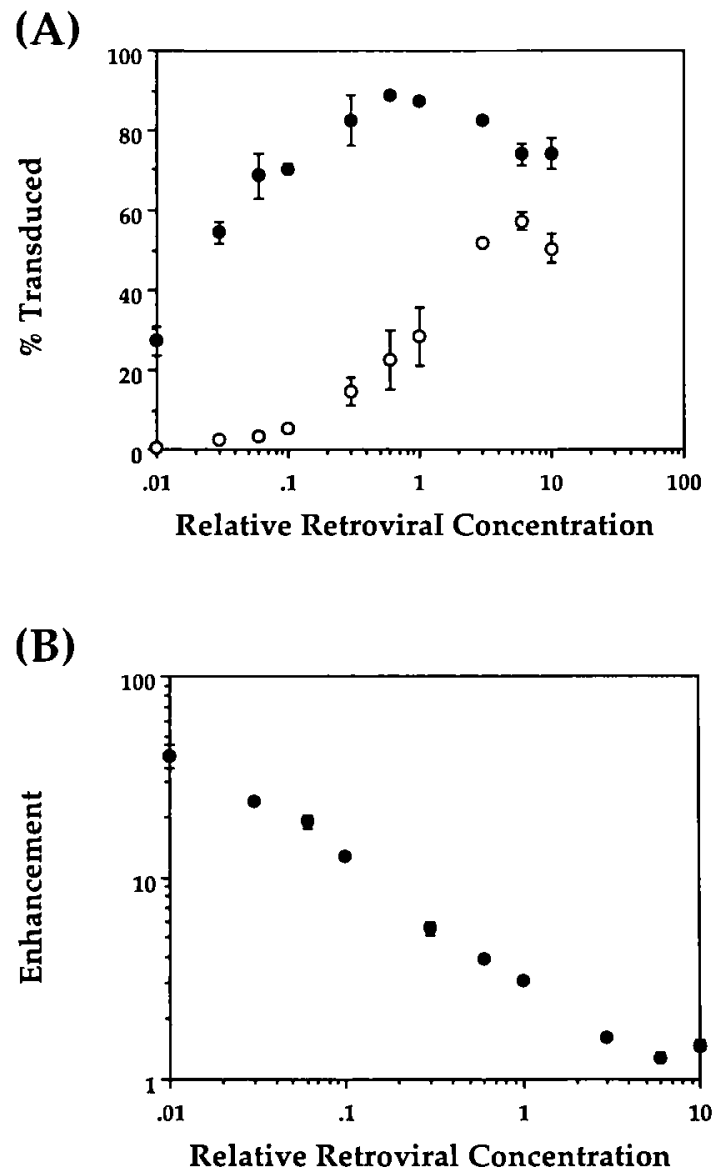

FIG. 5. Flow-through transduction and static transduction: Effect of virus concentration. Transduction efficiency $(\%$ Transduced) as a function of virus concentration was measured using flow-through $(O)$ and static $(O)$ methods of transduction (A). The concentration range spanned $10^{3}$-fold. The transduction period was $9 \mathrm{hr}$. Each data point represents the average of two independent samples. B. Gene transfer enhancements by flow-through transduction were calculated based on the average percentage of static transductions for each of the virus concentrations shown in Fig. 5A. 
(A)

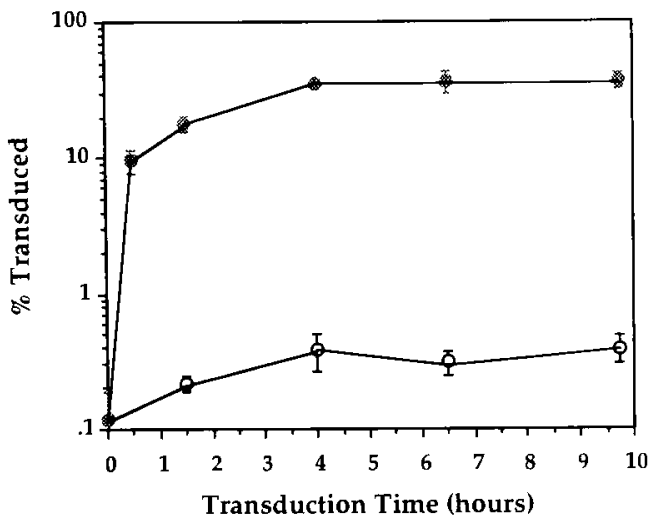

(B)

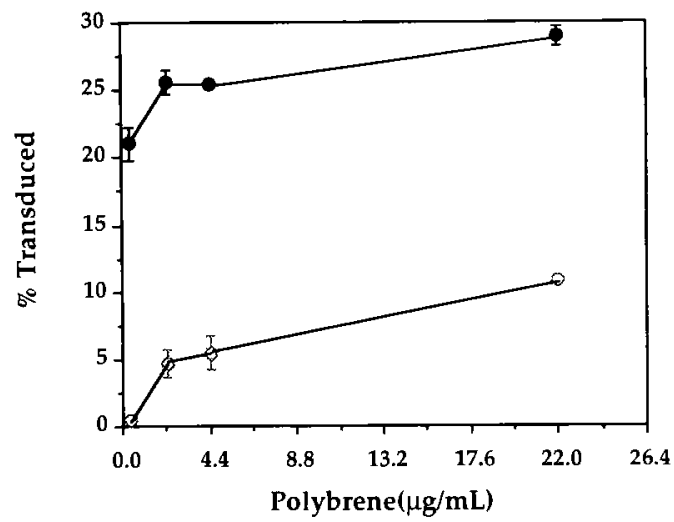

FIG. 6. A. Flow-through and static transduction: Transduction kinetics in the absence of polybrene. Transduction efficiency (\% Transduced) as a function of virus solution exposure time (Transduction Time) for flow-through (-) and static $(\mathrm{O})$ transductions. No polybrene was used in the virus solution. Each data point represents the average of two independent samples. B. Polybrene dose response. Transduction efficiency as a function of polybrene concentration was measured for flow-through $(0)$ and static $(O)$ transductions. The transduction period was $9 \mathrm{hr}$. Each data point represents the average of two independent samples.

transfer (Fig. 6). The transduction efficiencies as a function of time show that over $35 \%$ of $3 \mathrm{~T} 3$ target cells could be transduced within $4 \mathrm{hr}$ without using polybrene, whereas insignificant numbers of cells were transduced using the static method in the absence of polybrene (Fig. 6A). A relative retroviral concentration of 0.75 was used for both experiments (Fig. 6A,B). The dependence of the two transduction methods on polybrene was examined further by varying polybrene levels from 0.44 to $22 \mu \mathrm{g} / \mathrm{ml}$ (Fig. 6B). The flow-through method was much less sensitive to the concentration of polybrene than the static method. For polybrene concentrations higher than $2.2 \mu \mathrm{g} / \mathrm{ml}$, the transduction efficiencies increased at a much slower rate for the flow-through method as compared to the static method. Thus, not only could gene transfer occur to a significant number of target cells with no or very low polybrene levels, but higher polybrene levels became much less efficacious. As ex- pected, the polybrene levels did not affect the fluid flow rates through the porous membranes (data not shown).

\section{DISCUSSION}

The recognition that Brownian motion limits the number of retroviruses that can reach target cells using static transduction methods has led to the development of flow-through transduction. The flow-through method has been shown to be able to enhance significantly the number of transductions over that obtained by static methods. In the present study we show that: (i) the number of transduced cells obtained using static transduction methods is strongly dependent on virus concentration, and that a peak number of transduced cells is obtained at an "optimal" virus concentration; (ii) flow-through transductions are much less sensitive to virus concentration and a consistently high number of transduced cell can be obtained over a wide range of virus concentrations; and (iii) polybrene is not needed to obtain a high number of transduced cells using the flowthrough method.

It has been documented that the number of transduced cells depends linearly on retrovirus concentration at low titers (e.g., Chuck, 1995). The data presented here show that there is a limit to this increase and that a maximum or a plateau is reached at elevated virus concentrations. Such a plateau has been observed by others (Paul et al., 1993), and suggests there is a limit to how much increased viral titer can improve retrovirus-mediated gene transfer rates. However, because the retrovirus solutions used were only concentrated supernatants and not purified, it should be noted that effects associated with high virus titer cannot be distinguished from high concentrations of other nonviral components of the supernatant (e.g., growth inhibitors and other factors in conditioned medium that may compete with the virus for receptor binding). Thus, the optimal virus concentration values observed here can be more rigorously described as the optimal dilutions of the virus supernatant used.

In general, a virus can be considered a multivalent ligand (e.g., Lauffenburger and Linderman, 1993). In such cases, the ligand concentration is expected to affect the degree of receptor crosslinking (Wickham et al., 1990; Lauffenburger and Linderman, 1993). In other ligand-binding systems, different degrees of crosslinking have been observed to lead to different cellular responses (e.g., MacGlashan et al., 1985; Baird et al., 1988). Further, it has been proposed that the number of receptors available for binding is determined by the relative rates of receptor internalization and subsequent receptor recovery (Zigmond $e t$ al., 1982). The extent of receptor recovery in polymorphonuclear leukocyte cells was found to increase, peak, then decrease with ligand concentration (Zigmond et al., 1982). Although the mechanism(s) by which a retrovirus binds and internalizes has not been fully defined, optimum relationships found in multivalent ligand binding systems may apply to retroviral entry, and thus determine the probability of successful gene transfer.

The availability of receptors on the cell determines the amount of ligand, or viruses, that can bind. Polybrene is believed to act to reduce electrostatic repulsion between the negatively charged bilipid layers on the virus and the target cell (Coelen et al., 1983; Aubin et al., 1994). The effect of polybrene on static transductions was found to be significant (Fig. 
$4,6 \mathrm{~B})$. These results suggest that polybrene acts by increasing the receptor availability of target cells to transduction. In using flow-through to reduce the distance the virus must travel to the target cells, the contact frequency of the virus and target cells can be increased (e.g., Berg, 1983). Thus, a greater number of cell receptors may be apparent to the virus. In using flowthrough to achieve an enhanced contact frequency, the dependence on polybrene to make receptors available is offset. This mode of virus delivery is, in principle, also concentration independent because virus encounter with the target cell is dependent on fluid mechanics rather than random Brownian motion. Consistent with this expectation, the change in virus delivery method was found to reduce significantly the dependence of gene transfer on virus concentration (Fig. 5). Further, the adsorption characteristics of the virus to the porous membrane have been found to determine the likelihood of successful gene transfer (Chuck and Palsson, 1996). More importantly, the flow-through method does not rely on the use of polybrene. It has been shown that the virus can adsorb directly to the (neutral-charged) porous membrane in the absence of polybrene, enabling the target cells to encounter the adsorbed virus so that virus entry can subsequently take place (Chuck and Palsson, 1996).

The characteristics of the flow-through method of transduction may have significant implications for the use of retrovirusmediated gene transfer in gene therapy protocols. Flow-through transductions lead to transduction rates not achievable by static transduction. The ability to obtain high transduction rates even at low viral concentrations eliminates most of the concerns associated with the production of high-titer virus solutions. The insensitivity to viral titers eliminates the need to produce consistently retroviral supernatants at given virus concentrations. Flow-through transductions can be carried out without the use of polycations such as polybrene. Although no long-term effects on cell growth were observed with either the polybrene or retroviral concentration ranges used, it should be noted that any possible toxic effects associated with these solutions can be minimized using flow-through transductions. Last, the volume of viral supernatants needed for transduction can be sharply reduced. Taken together, these advantages of flow-through transductions are likely to lead to their widespread use for gene transfer work, both in research and clinical settings.

\section{ACKNOWLEDGMENTS}

We thank Stelios Andreadis and Oveta Fuller for valuable and insightful discussions, and Timothy Eisfeld for his help in concentrating the retrovirus solutions. We also thank James Wilson for kindly providing the retroviral packaging cell line used in this work, and Aastrom Biosciences, Inc. for funding this work.

\section{REFERENCES}

AUSUBEL, F.M. (1993). Introduction of DNA into mammalian cells. In Current Protocols in Molecular Biology. F.M. Ausubel, R. Brent,
R.E. Kingston, D.D. Moore, J.G. Seidman, J.A. Smith, and K. Struhl, eds. (John Wiley and Sons, Inc., New York).

AUBIN, R.A., WEINFELD, M., MIRZAYANS, R., and PATERSON, M.C. (1994). Polybrene/DMSO-assisted gene transfer. Mol. Biotechnol. 1, 29-48.

BAIRD, B., ERICKSON, J., GOLDSTEIN, B., KANE, P., MENON, A.K., ROBERTSON, D., and HOLOWKA, D. (1988). Progress toward understanding the molecular details and consequences of IgEreceptor crosslinking. In Theoretical Immunology, Part One. A.S. Perelson, ed. (Addison-Wesley Publishing Company, Redwood City, CA) pp. 41-59.

BELMONT, J.W., MACGREGOR, G.R., WAGER-SMITH, K., FLETCHER, F.A., MOORE, K.A., HAWKINS, D., VILLALON, D., CHANG, S.M.-W., and CASKEY, C.T. (1988). Expression of human adenosine deaminase in murine hematopoietic cells. Mol. Cell. Biol. 8, 5116-5125.

BERG, H.C. (1983). Random Walks in Biology. (Princeton University Press, NJ) p37-47.

BODINE, D.M., KARLSSON, S., and NIENHUIS, A.W. (1989). Combination of interleukins 3 and 6 preserves stem cell function in culture and enhances retrovirus-mediated gene transfer into hematopoietic stem cells. Proc. Natl. Acad. Sci. USA 86, 8897-8901.

BODINE, D.M., MCDONAGH, K.T., BRANDT, S.J., NEY, P.A., AGRICOLA, B., BYRNE, E., and NIENHUIS, A.W. (1990). Development of a high-titer retrovirus producer cell line capable of gene transfer into rhesus monkey hematopoietic stem cells. Proc. Natl. Acad. Sci. USA 87, 3738-3742.

BUCHSCHACHER, G.L., JR. (1993). Molecular targets of gene transfer therapy for HIV transduction. J. Am. Med. Assn. 269, 2880-2886.

CHUCK, A.S. (1995). "Directed retroviral motion as a means of enhancing gene transfer for gene therapy.' Ph.D. thesis, The University of Michigan, Ann Arbor, MI.

CHUCK, A.S., and PALSSON, B.O. (1996). Membrane adsorption characteristics determine the kinetics of flow-through transduction. Biotechnol. Bioeng. (accepted).

COELEN, R.J., JOSE, D.G., and MAY, J.T. (1983). The Effect of hexadimethrine bromide (Polybrene) on the transduction of the primate retroviruses SSV1/SSAV1 and BaEV. Arch. Virol. 75, 307-311.

CORNETTA, K., and ANDERSON, W.F. (1989). Protamine sulfate as an effective alternative to polybrene in retroviral-mediated genetransfer: implications for human gene therapy. J. Virol. Methods 23, 1187-1194.

CRYSTAL, R.G. (1995). Transfer of genes to humans: Early lessons and obstacles to success. Science 270, 404-410.

CUSSLER, E.L. (1984). Difid Systems. (Cambridge University Press, New York) p. 118.

DANOS, O., and MULLIGAN, R.C. (1988). Safe and efficient generation of recombinant retroviruses with amphotropic and ecotropic host ranges. Proc. Natl. Acad. Sci USA 85, 6460-6464.

DUBOIS-DALCQ, M., HOLMES, K.V, and RENTIER, B. (1984). Assembly of Enveloped RNA Viruses. (Springer-Verlág, New York) pp. 149-170.

EINSTEIN, A. (1905). Über die von der molekularkinetischen Theorie der Wärme geforderte Bewegung von in ruhenden Flüssigkeiten suspendierten Teilchen. Annalen der Physik. 17, 549-560.

HODGSON, C.P. (1995). The void in gene therapy. Bio/Technology 13, 222-225.

HUGHES, PF.D., THACKER, J.D., HOGGE, D., SUTHERLAND, H.J., THOMAS, T.E., LANDSORP, P.M., EAVES, C.J., and HUMPHRIES, R.K. (1992). Retroviral gene transfer to primitive normal and leukemic hematopoietic cells using clinically applicable procedures. J. Clin. Invest. 89, 1817-1824.

KAPLAN, M.M.WHTOR, T.J., MAES, R.F., CAMPBELL, J.B., and KOPROWSKI, H. (1967). Effect of polyions on the infectivity of rabies virus in tissue culture: Construction of a single-cycle growth curve. J. Virol. 1, 145-151. 
KOTANI, H., NEWTON, P.B. III, ZHANG, S., CHIANG, Y.L., OTTO, E., WEAVER, L., BLAESE, R.M., ANDERSON, W.F., and MCGARRITY, G.J. (1994). Improved methods of retroviral vector transduction and production for gene therapy. Hum. Gene Ther. 5, 19-28.

LAUFFENBURGER, D.A., and LINDERMAN, J.L. (1993). Receptors: Models for binding, trafficking, and signaling. (Oxford University Press, New York).

LAYNE, S.P., SPOUGE, J.L., and DEMBO, M. (1989). Quantifying the infectivity of human immunodeficiency virus. Proc. Natl. Acad. Sci. USA 86, 4644-4648.

LEVIN, J.G., and ROSENAK, M.J. (1976). Synthesis of murine leukemia virus proteins associated with virions assembled in actinomycin D-treated cells: Evidence for persistence of viral messenger RNA. Proc. Natl. Acad. Sci. USA 73, 1154-1158.

LOWY, D.R. (1985). Transformation and oncogenesis: Retroviruses. In Virology. B.N. Fields, D.M. Knipe, J.L. Melnick, R.M. Chanock, and B. Roizman, eds. (Raven Press, New York) p. 237.

LYNCH, C.M., and MILLER, A.D. (1991). Production of high-titer helper virus-free retroviral vectors by cocultivation of packaging cells with different host ranges. J. Virol. 65, 3887-3890.

MACGLASHAN, D.W., JR., DEMBO, M., and GOLDSTEIN, B. (1985). Test of a theory relating to the cross-linking of IgE antibody on the surface of human basophils. J. Immunol. 135, 4129-4134.

MILLER, A.D. (1992a). Human gene therapy comes of age. Nature 357, 455-460.

MILLER, A.D. (1992b). Retroviral vectors. Curr. Topics Microbiol. Immunol. 158, 1-24.

MULLIGAN, R.C. (1993). The basic science of gene therapy. Science 260, 926-932.
PAUL, R.W., MORRIS, D., HESS, B.W., DUNN, J., and OVERELL R.W. (1993). Increased viral titer through concentration of viral harvests from retroviral packaging cell lines. Hum. Gene Ther. 4, 609-615.

SANES, J.R., RUBENSTEIN, J.L.R., and NICOLAS, J-F. (1986). Use of a recombinant retrovirus to study post-implantation cell lineage in mouse embryos. EMBO J. 5, 3133-3142.

WICKHAM, T.J., GRANADOS, R.R., WOOD, H.A., HAMMER, D.A., and SHULER, M.L. (1990). General analysis of receptor-mediated viral attachment to cell surfaces. Biophys. J. 58, 1501-1516.

WILSON, J.M., JEFFERSON, D.M., CHOWDHURY, J.R., NOVIKOFF, P.M., JOHNSTON, D.E., and MULLIGAN, R.C. (1988). Retrovirus-mediated transduction of adult hepatocytes. Proc. Natl. Acad. Sci. USA 85, 3014-3018.

ZIGMOND, S.H., SULLIVAN, S.J., and LAUFFENBURGER, D.A. (1982). Kinetic analysis of chemotactic peptide receptor modulation. J. Cell Biol. 92, $34-43$.

$$
\begin{array}{r}
\text { Address reprint requests to: } \\
\text { Dr. Bernhard O. Palsson } \\
\text { Department of Bioengineering } \\
\text { University of California, San Diego } \\
9500 \text { Gilman Drive } \\
\text { La Jolla, CA 92093-0412 }
\end{array}
$$

Received for publication September 5, 1995; accepted after revision December 22, 1995. 


\section{This article has been cited by:}

1. John Yin. 2007. Chemical engineering and virology: Challenges and opportunities at the interface. AIChE Journal 53:9, 2202-2209. [CrossRef]

2. A. S. Coroadinha, P. M. Alves, S. Sá Santos, P. E. Cruz, O.-W. Merten, M. J. T. Carrondo. 2006. Retrovirus producer cell line metabolism: implications on viral productivity. Applied Microbiology and Biotechnology 72:6, 1125-1135. [CrossRef]

3. A.S. Coroadinha, J. Ribeiro, A. Roldão, P.E. Cruz, P.M. Alves, O.-W. Merten, M.J.T. Carrondo. 2006. Effect of medium sugar source on the production of retroviral vectors for gene therapy. Biotechnology and Bioengineering 94:1, 24-36. [CrossRef]

4. Pedro Lei, Stelios T. Andreadis. 2005. Stoichiometric limitations in assembly of active recombinant retrovirus. Biotechnology and Bioengineering 90:7, 781-792. [CrossRef]

5. Natalia LandDzuri, Joseph M. Le Doux. 2005. Complexation of retroviruses with charged polymers enhances gene transfer by increasing the rate that viruses are delivered to cells. The Journal of Gene Medicine 6:12, 1304-1319. [CrossRef]

6. Robert M. Saller, Stefano Indraccolo, Vincenzo Coppola, Giovanni Esposito, Jan Stange, Steffen Mitzner, Alberto Amadori, Brian Salmons, Walter H. GDnzburg. 2002. Encapsulated cells producing retroviral vectors forin vivo gene transfer. The Journal of Gene Medicine 4:2, 150-160. [CrossRef]

7. Young Jik Kwon, Hong Yu, Ching-An Peng. 2001. Enhanced retroviral transduction of 293 cells cultured on liquid-liquid interfaces. Biotechnology and Bioengineering 72:3, 331-338. [CrossRef]

8. Yutaka Hanazono, Keiji Terao, Keiya Ozawa. 2001. Gene Transfer into Nonhuman Primate Hematopoietic Stem Cells: Implications for Gene Therapy. Stem Cells 19:1, 12-23. [CrossRef]

9. David A. Williams , Franklin O. Smith . 2000. Progress in the Use of Gene Transfer Methods to Treat Genetic Blood DiseasesProgress in the Use of Gene Transfer Methods to Treat Genetic Blood Diseases. Human Gene Therapy 11:15, 2059-2066. [Abstract] [PDF] [PDF Plus]

10. Yutaka Hanazono, Kevin E. Brown, Cynthia E. Dunbar . 2000. Primary T Lymphocytes as Targets for Gene TherapyPrimary T Lymphocytes as Targets for Gene Therapy. Journal of Hematotherapy Stem Cell Research 9:5, 611-620. [Abstract] [PDF] [PDF Plus]

11. Burkhard Hennemann, Jean Y. Chuo, Patricia D. Schley, Karen Lambie, R. Keith Humphries, Connie J. Eaves . 2000. High-Efficiency Retroviral Transduction of Mammalian Cells on Positively Charged SurfacesHigh-Efficiency Retroviral Transduction of Mammalian Cells on Positively Charged Surfaces. Human Gene Therapy 11:1, 43-51. [Abstract] [PDF] [PDF Plus]

12. Mauro Di Ianni , Sabrina Di Florio, Gigliola Venditti, Franca Falzetti , P. Mannoni , Massimo F. Martelli , Antonio Tabilio . 1999. T Lymphocyte Transduction with Herpes Simplex VirusThymidine Kinase (HSV-tk) Gene: Comparison of Four Different Infection ProtocolsT Lymphocyte Transduction with Herpes Simplex VirusThymidine Kinase (HSV-tk) Gene: Comparison of Four Different Infection Protocols. Journal of Hematotherapy Stem Cell Research 8:6, 645-652. [Abstract] [PDF] [PDF Plus]

13. Dao Pan, Chester B. Whitley. 1999. Closed hollow-fiber bioreactor: a new approach to retroviral vector production. The Journal of Gene Medicine 1:6, 433-440. [CrossRef]

14. Dao Pan , Raji Shankar, David F. Stroncek, Chester B. Whitley . 1999. Combined Ultrafiltration-Transduction in a Hollow-Fiber Bioreactor Facilitates Retrovirus-Mediated Gene Transfer into Peripheral Blood Lymphocytes from Patients with Mucopolysaccharidosis Type IICombined Ultrafiltration-Transduction in a Hollow-Fiber Bioreactor Facilitates Retrovirus-Mediated Gene Transfer into Peripheral Blood Lymphocytes from Patients with Mucopolysaccharidosis Type II. Human Gene Therapy 10:17, 2799-2810. [Abstract] [PDF] [PDF Plus]

15. Karen E. Pollok, Johannes C.M. Van Der Loo, Ryan J. Cooper, Lorrie Kennedy, David A. Williams . 1999. Costimulation of Transduced T Lymphocytes via T Cell Receptor-CD3 Complex and CD28 Leads to Increased Transcription of Integrated RetrovirusCostimulation of Transduced T Lymphocytes via T Cell Receptor-CD3 Complex and CD28 Leads to Increased Transcription of Integrated Retrovirus. Human Gene Therapy 10:13, 2221-2236. [Abstract] [PDF] [PDF Plus] 
16. Charles M. Roth, Martin L. Yarmush. 1999. Nucleic Acid Biotechnology. Annual Review of Biomedical Engineering 1:1, 265-297. [CrossRef]

17. Jeffrey C. Marx , James A. Allay, Derek A. Persons, Sharon A. Nooner, Phillip W. Hargrove, Patrick F. Kelly, Elio F. Vanin , Edwin M. Horwitz . 1999. High-Efficiency Transduction and Long-Term Gene Expression with a Murine Stem Cell Retroviral Vector Encoding the Green Fluorescent Protein in Human Marrow Stromal CellsHigh-Efficiency Transduction and Long-Term Gene Expression with a Murine Stem Cell Retroviral Vector Encoding the Green Fluorescent Protein in Human Marrow Stromal Cells. Human Gene Therapy 10:7, 1163-1173. [Abstract] [PDF] [PDF Plus]

18. Ai Guo Wu , Xia Liu Amitabha Mazumder, Joseph Alfonso Bellanti, Kenneth Robert Meehan . 1999. Improvement of Gene Transduction Efficiency in T Lymphocytes Using Retroviral VectorsImprovement of Gene Transduction Efficiency in T Lymphocytes Using Retroviral Vectors. Human Gene Therapy 10:6, 977-982. [Abstract] [PDF] [PDF Plus]

19. MARIANNE HUTCHINGS, KOICHI MORIWAKI, DAGMAR DILLOO, THOMAS HOFFMANN, SARAH KIMBROUGH, HANS E. JOHNSEN, MALCOLM K. BRENNER, HELEN E. HESLOP. 1998. Increased Transduction Efficiency of Primary Hematopoietic Cells by Physical Colocalization of Retrovirus and Target CellsIncreased Transduction Efficiency of Primary Hematopoietic Cells by Physical Colocalization of Retrovirus and Target Cells. Journal of Hematotherapy 7:3, 217-224. [Abstract] [PDF] [PDF Plus]

20. Joseph M. Le Doux, Jeffrey R. Morgan, Martin L. Yarmush. 1998. Removal of proteoglycans increases efficiency of retroviral gene transfer. Biotechnology and Bioengineering 58:1, 23-34. [CrossRef]

21. Mojgan Movassagh, Christine Desmyter, Claude Baillou, Sylvie Chapel-Fernandes, Martine Guigon, David Klatzmann, Francois M. Lemoine. 1998. High-Level Gene Transfer to Cord Blood Progenitors Using Gibbon Ape Leukemia Virus Pseudotype Retroviral Vectors and an Improved Clinically Applicable ProtocolHigh-Level Gene Transfer to Cord Blood Progenitors Using Gibbon Ape Leukemia Virus Pseudotype Retroviral Vectors and an Improved Clinically Applicable Protocol. Human Gene Therapy 9:2, 225-234. [Abstract] [PDF] [PDF Plus]

22. Helmut Hanenberg, Kimikazu Hashino, Haruko Konishi, Randy A. Hock, Ikunoshin Kato, David A. Williams. 1997. Optimization of Fibronectin-Assisted Retroviral Gene Transfer into Human CD34+ Hematopoietic CellsOptimization of Fibronectin-Assisted Retroviral Gene Transfer into Human CD34+ Hematopoietic Cells. Human Gene Therapy 8:18, 2193-2206. [Abstract] [PDF] [PDF Plus]

23. M. E. Grossmann, M. P. Brown, M. K. Brenner. 1997. Antitumor Responses Induced by Transgenic Expression of CD40 LigandAntitumor Responses Induced by Transgenic Expression of CD40 Ligand. Human Gene Therapy 8:16, 1935-1943. [Abstract] [PDF] [PDF Plus]

24. CAROLINE G.L. LEE, KUAN-TEH JEANG, MALCOLM A. MARTIN, IRA PASTAN, MiCHAEL M. GOTTESMAN. 1997. Efficient Long-Term Coexpression of a Hammerhead Ribozyme Targeted to the U5 Region of HIV-1 LTR by Linkage to the Multidrug-Resistance GeneEfficient Long-Term Coexpression of a Hammerhead Ribozyme Targeted to the U5 Region of HIV-1 LTR by Linkage to the Multidrug-Resistance Gene. Antisense and Nucleic Acid Drug Development 7:5, 511-522. [Abstract] [PDF] [PDF Plus]

25. Menzo Havenga, Peter Hoogerbrugge, Dinko Valerio, Helmuth H. G. van Es. 1997. Retroviral Stem Cell Gene Therapy. Stem Cells 15:3, 162-179. [CrossRef]

26. Patrizia Comoli, Dagmar Dilloo, Marianne Hutchings, Thomas Hoffman, Helen E. Heslop. 1997. Measuring gene-transfer efficiency. Nature Medicine 2:12, 1280-1281. [CrossRef]

27. Clay Smith, Kenneth Phillips. 1997. Reply to "Measuring gene-transfer efficiency". Nature Medicine 2:12, 1281-1281. [CrossRef]

28. A. S. Chuck, M. F. Clarke, B. O. Palsson. 1996. Retroviral Infection Is Limited by Brownian MotionRetroviral Infection Is Limited by Brownian Motion. Human Gene Therapy 7:13, 1527-1534. [Abstract] [PDF] [PDF Plus] 